\title{
Teachers' Attitudes and Beliefs about Homosexuality
}

\author{
Carles Pérez -Testor ${ }^{1}$, Julia Behar ${ }^{2}$, Montse Davins ${ }^{1}$, José Luís Conde \\ Sala $^{2}$, José. A. Castillo ${ }^{1}$, Manel Salamero ${ }^{1}$, Elisabeth Alomar ${ }^{1}$, \\ and Sabina Segarra ${ }^{1}$ \\ ${ }^{1}$ Universitat Ramon Llull (Spain) \\ ${ }^{2}$ Universitat de Barcelona (Spain)
}

\begin{abstract}
Schools play a key role in transmitting attitudes towards sexual diversity. Many studies stress the importance of teachers' and other professionals' attitudes towards gay men and/or lesbian women. This study evaluates attitudes and prejudices toward homosexuality in a sample of 254 elementary and high school teachers in Barcelona and its surrounding area. The results obtained using a scale of overt and subtle prejudice and a scale of perceived discrepancy of values indicate that discrepancy between likely behavior and personal values was significantly greater in women, those who hold religious beliefs, churchgoers and people without any gay or lesbian acquaintances. Approximately $88 \%$ of the teachers showed no type of prejudiced attitudes towards gay men and lesbian women. The experience of proximity to gay men and/or lesbian women reduces not only the discrepancy between personal values and likely behavior but also the presence of homophobic prejudice. It would be advisable to expand specific teacher training in the subject of sexual diversity in order to reduce prejudicial attitudes, thus fostering non-stereotyped knowledge of homosexuality.

Keywords: attitudes toward gay men and lesbian women, subtle prejudice, overt prejudice, homophobia, teachers.
\end{abstract}

La escuela juega un rol clave en la transmisión de actitudes hacia la diversidad sexual. Muchos estudios subrayan la importancia de las actitudes de los profesores y de otros profesionales hacia hombres gay y/o mujeres lesbianas. Este estudio evalúa actitudes y prejuicios hacia la homosexualidad en una muestra de 254 profesores de escuelas de primaria y secundaria de Barcelona y su zona metropolitana. Los resultados obtenidos al aplicar una escala de prejuicio manifiesto y sutil, y una escala de discrepancia percibida de valores, indican que la discrepancia entre la conducta probable y los valores personales son significativamente mayores en mujeres, aquellos que tienen creencias religiosas, los que practican la religión y las personas que no conocen a gays o lesbianas. Aproximadamente el $88 \%$ de los profesores no mostraron ningún tipo de actitudes prejuiciosas hacia los gays y lesbianas. La experiencia de proximidad a hombres gay y/o mujeres lesbianas no sólo reduce la discrepancia entre los valores personales y la conducta probable sino también la presencia de prejuicio homófobo. Sería recomendable ampliar la formación específica del profesorado en el tema de la diversidad sexual para reducir actitudes prejuiciosas, fomentando así un conocimiento de la homosexualidad no estereotipado.

Palabras clave: actitudes, hombres gay, mujeres lesbianas, prejuicio sutil, prejuicio manifiesto, homofobia, profesores.

Correspondence concerning this article should be addressed to Dr. Carles Pérez Testor. Instituto Universitario de Salud Mental Vidal y Barraquer (Universidad Ramon Llull). C/ Sant Gervasi de Cassoles, 88. 08022 Barcelona (Spain). E.mail: carlespt@fvb.cat 
Although sexual diversity has undoubtedly become more widely accepted, democratic societies continue to exert a strong social pressure on the lesbian and gay minority to limit their visibility. In spite of social permissiveness, covert homophobia continues to exist and may have more serious consequences than that which is explicitly expressed (Steffens, 2005). The presence of normative pressure in favour of equality and tolerance has not eliminated this type of prejudice, but rather has rendered it more subtle and sophisticated (Espelt, Javaloy \& Cornejo, 2006).

When it comes to the possible transmission of such prejudice, schools play a key role. Teachers are a group of professionals whose educational responsibilities mean that they may influence whether or not their pupils develop attitudes of prejudice or respect toward sexual diversity (Farr, 2000). Addressing diversity means that each individual pupil will have sufficient opportunities to make the most of his or her capacities within a framework where the challenge is to achieve equality through the acceptance of difference. In meeting this objective, the attitudes and beliefs transmitted by teachers, as well as their training in such issues, are of fundamental importance (Martínez, 2005; Montero, 2000; Sánchez, 2002). In other forms of victimization, such as bullying, there has been shown to be a relationship between the teachers' attitudes and beliefs and their handling and intervention strategies (Kochenderfer-Ladd \& Pelletier, 2007). As Benkov (1994) pointed out, homophobia is reflected in the classroom in different ways, including the transmission of rigid assumptions about gender roles.

Prejudice, understood as a negative affective disposition toward a group or its members, has been widely studied within social psychology. Traditionally this discipline has focused more on racial prejudice, but recently prejudice toward social groups such as homosexuals has also been considered. In line with Pettigrew and Meertens (1995), Quiles del Castillo, Betancor, Rodríguez, Rodríguez and Coello (2003) distinguish between 'overt' homophobia and 'subtle' homophobia. The classical 'overt' form involves the expression of prejudice through hostility and rejection in a forceful and direct way. In contrast, the subtle form implies the expression of prejudice in a veiled and indirect way, for example, by stating that gay men and lesbian women have different ideas, beliefs and values to heterosexuals, and that they do not follow the customs of the majority. Marinho, Marques, Almeida, Menezes and Guerra (2004) found implicit and explicit prejudice to be different constructs, thus corroborating the need to evaluate both forms.

Devine (1989) maintains that although individuals both high and low in prejudice have knowledge of cultural stereotypes and thus experience activation of the stereotype in the presence of stigmatized individuals, low-prejudiced individuals work to avoid applying the stereotype. She interpreted this increased effort on the part of low-prejudice individuals as being intrinsically as opposed to extrinsically motivated. Herek (2004) claims that sexual prejudice does not always allow us to predict specific behaviors, but heterosexuals with a high level of sexual prejudice do tend to respond negatively to gay or lesbian subjects in a way that influences their behavior.

Most studies of homophobia are based on undergraduate samples from different countries (Ben-Ari, 1998; Buston \& Hart, 2001; Cullen, Wright \& Alessandri, 2002; Donnelly, et al., 1997; Johnson, Brems \& Alford-Keating, 1997; Jones, Pynor, Sullivan \& Weerakoon, 2002; Keuzenkamp \& Bos, 2007; Lieblich \& Friedman, 1985; Maney \& Cain 1997; Matchinsky \& Iverson, 1996; Sakalli, 2002; Span \& Vidal, 2003; Van de Ven, 1995; Waterman, Reid, Garfield $\&$ Hoy, 2001). However, the presence of homophobia has also been investigated in various professional groups: military personnel (Lingiardi, Falanga \& D'Augelli, 2005), social workers (Berkman \& Zinberg, 1997), counselling practitioners (Bowers, Plummer \& Minichiello, 2005; Satcher \& Leggett, 2007), doctors (Smith \& Mathews, 2007), nurses (Röndahl, Innala \& Carlsson, 2004), and physical education teachers (Morrow \& Gill, 2003).

In addition, several studies have been conducted to assess homophobia and its possible relationship with certain variables: gender, religious beliefs, and having had contact with gay men and/or lesbian women. The studies reviewed reveal greater homophobia among people with stronger or more rigid religious beliefs (Berkman \& Zimberg, 1997; Johnson et al., 1997; Maney \& Cain, 1997; Morrison \& Morrison, 2002; Toro-Alfonso \& Varas-Díaz, 2004). Although some studies report contradictory results with respect to gender and homophobia (e.g. Proulx, 1997), the majority show men to be more homophobic than women (Donnelly et al., 1997; Johnson et al., 1997; Jones et al., 2002; Lieblich \& Friedman, 1985; Lingiardi et al., 2005; Maney \& Cain, 1997; Sakalli, 2002; Steffens, 2005). There is also consensus among various studies that having contact with homosexual people is predictive of fewer homophobic attitudes or, to put it another way, a lack of contact with lesbian women and gay men is correlated with negative attitudes (Berkman \& Zinberg, 1997; Cullen et al., 2002; Sakalli, 2002; Shidlo, 1994; Span \& Vidal, 2003; Toro-Alfonso \& Varas-Díaz, 2004; Waterman et al., 2001). As Farr (2000) points out, it would seem that the most powerful stimulus of homophobia is the belief that "I don't know any homosexuals".

As regards empirical research in our country, Spain, studies of homophobia have only been conducted with medical students (España, Guerrero, Farré, Canella-Soler \& Abós, 2001) and psychology undergraduates (Quiles del Castillo et al., 2003). As far as we know, there are no studies in the literature that examine homophobic attitudes of teachers, nor subtle, manifest prejudice towards gay men and lesbian women. Given this, the aims of the present 
Table 1

Participants' characteristics

\begin{tabular}{lrr}
\hline & $N$ & $\%$ \\
\hline Sex & & \\
Male & 40 & 15.9 \\
Female & 212 & 84.1 \\
Marital status & 88 & 31.6 \\
$\quad$ Single & 39 & 46.4 \\
Living with a stable partner & 119 & 5.5 \\
$\quad$ Married & 14 & 15.8 \\
$\quad$ Separated and/or divorced & & \\
Where from & 117 & 46.2 \\
$\quad$ City of Barcelona & 137 & 53.8 \\
Other places in Catalonia & & \\
Education & 132 & 52.2 \\
$\quad$ Diploma & 121 & 47.8 \\
Bachelor's degree & & \\
Educational level at which the teacher works & 91 & 36 \\
$\quad$ Infant & 60 & 23.7 \\
$\quad$ Primary & 102 & 40.3 \\
$\quad$ Secondary & & \\
Type of centre in which the teacher works & 118 & 47.6 \\
$\quad$ Public & 21 & 8.5 \\
Private & & 43.9 \\
State-subsidized private & 109 & 62.2 \\
Do you have any religious beliefs? & & 37.8 \\
$\quad$ Yes & 150 & 25.6 \\
No & 91 & 74.4 \\
Are you a churchgoer? & & 62 \\
$\quad$ Nos & 180 & \\
$\quad$ & & \\
\hline
\end{tabular}

study were: (a) to assess acceptance of sexual diversity by means of the discrepancy between how people think they should feel in different types of contact with a homosexual person (personal values) and how they think they will actually feel (likely behavior); (b) to analyze the existence of subtle and overt prejudice toward gay men and lesbian women; and (c) to analyze the relationships between these dimensions and socio-demographic variables.

\section{Method}

\section{Participants}

Agroup of infant, primary and secondary school teachers taking a continuing education course in Barcelona (Spain) were asked to participate. This continuing education is an activity required of all teachers in both public and private schools, as a way of improving the quality of teaching. It takes places in "summer schools" held in July, once the academic year is over. The first day of class, a researcher from the group asked the teachers to voluntarily and anonymously participate in the study, and he handed out the material with the questionnaires to be completed. A total of 254 teachers ( $84.1 \%$ female) responded in person and returned the material to the researcher.

The mean age of the teachers was 35.4 years (SD: 9.0; range: 21-64). Almost half the teachers were married (46.4\%), while the remainder were either single (31.6\%) or living with a stable partner (15.8\%). Of the teachers, $52.5 \%$ held diplomas and the remainder Bachelor's degrees; $46.2 \%$ of them lived in Barcelona, while the others came from other parts of Catalonia. Table 1 summarizes participant characteristics (variations in $\mathrm{N}$ are due to the fact that some subjects did not respond to all the questions).

\section{Instruments}

The instruments used in the study were the Discrepancy Between Personal Values and Likely Behavior Scale and the Subtle and Overt Prejudice Toward Homosexuals Scale, 
both adapted from Quiles del Castillo et al. (2003). On a separate sheet they were asked for socio-demographic variables: age, sex, marital status, education, school grade they taught, kind of school and religious beliefs and practices. Before administering the questionnaires, a researcher gave the instructions for filling them out and remained in the classroom while the participants responded, in case any queries should arise.

The Discrepancy Between Personal Values and Likely Behavior Scale presents different scenarios of proximity to a homosexual person. In our study we distinguished between situations involving gay men (seven situations) and the same situations with respect to lesbian women (seven situations). In addition, one situation made reference to both gay men and lesbian women. For example: "Imagine that a man sits next to you on the bus and you consider that he is gay", or "Imagine that you have to do a project for various subjects and someone in your class, who everybody knows is lesbian, says she wants to work with you". Therefore, participants expressed their opinion on a total of 15 scenarios, each of which they had to score on two seven-point scales (1 = "no, not at all"; 7 = "yes, totally"): (a) According to your personal values, do you think you should feel upset in this situation? (Personal Value Scale); and (b) Based on your experience, do you think you would actually feel upset? (Likely Behavior Scale).

Following Quiles del Castillo et al., the five items from the Personal Values and Likely Behavior with the greatest discrepancy were chosen. These five items with the greatest discrepancy were chosen to create three different indexes: (a) Personal Values Index (the mean score for responses on the personal values scale), (b) Likely Behavior Index (the mean score for responses on the likely behavior scale), and (c) Discrepancy Index (the latter being derived by subtracting the Personal Values Index from the Likely Behavior Index). Cronbach's alpha coefficients were .87 (95\% CI: .84, .89) for the personal values scale, .90 (95\% CI: .88, .92) for the likely behavior scale and $.86(95 \% \mathrm{CI}$ : $.83, .89)$ for the discrepancy scale. Quiles del Castillo et al., obtained similar values (.78, .84, and .74, respectively).

The Subtle and Overt Prejudice Toward Homosexuals Scale was developed by adapting items from the homosexual prejudice scale of Quiles del Castillo et al. These authors distinguish between 'overt' homophobia (a traditional form of prejudice revealed through hostile behavior and rejection) and 'subtle' homophobia (a more covert form of prejudice). Some of the original items were split in order to balance the items referring to gay men and lesbian women, and thus our instrument is an adaptation that includes 15 situations, the last five of which focus on subtle prejudice. These five items are the ones that saturate the first factor of cultural differences and values in the analysis by Quiles del Castillo et al.
For example: "Homosexuals and heterosexuals will never feel comfortable with one another, even if they are actually friends", or "Just as immigrants adopt the customs of the country they move to, I think that homosexuals could do the same and be more moderate". Each statement is scored on a seven-point Likert scale $(1=$ "disagree" -absence of prejudice-; 7 = "agree" -maximum prejudice-). Cronbach's alpha coefficients were .71 (95\% CI: .65, .76) for the explicit homophobia scale and .79 (95\% CI: .74, $.82)$ for the implicit homophobia scale. Quiles del Castillo et al. obtained similar values (.71 and .63, respectively).

To get the score for subtle and overt homophobia, the average of the items was calculated, with a range of one to seven for both scales. Following the procedure in Quiles del Castillo et al., the sample was divided into two groups with high and low scores compared to the theoretical average of both scales. This provided three basic types of individuals: egalitarian, with low scores on overt and subtle homophobia; subtle, with low scores on overt and high scores on subtle homophobia; and fanatics, with high scores on both scales.

\section{Statistical Analyses}

The variables showed non-normal distributions and therefore non-parametric statistics were used. The difference in central tendency of the independent groups was analyzed using either the Mann-Whitney or Wilcoxon test. The paired variables of personal values and likely behavior were compared using the Kruskal-Wallis test. In the analysis involving marital status, one widowed person and a member of a religious community were eliminated. In addition, married subjects and those with a long-term partner were grouped together. For the analysis of age, participants were divided into two groups around the median.

\section{Results}

We evaluated the discrepancy between personal values and likely behavior and prejudice toward gay men and lesbian women according to the educational level at which each teacher worked, their type of school, any religious beliefs they held, and whether or not they currently have or have had any gay men and/or lesbian women as friends. With regard to this last variable, $75.5 \%$ of the participants responded that they have or have had a gay friend, and $49.8 \%$ a lesbian friend. Of the teachers, $46.5 \%$ have or have had gay boys and/or lesbian girls as students.

\section{Discrepancy Between Personal Values and Likely Behavior}

On the Discrepancy Between Personal Values and Likely Behavior Scale the mean score participants 
on the personal values scale was $M=1.9(S D=1.0)$, while the corresponding mean on the likely behavior scale was $M=2.6(S D=.9)$. The discrepancy between personal values and likely behavior was low $(M=.8$, $S D=.9$ ). However, the score on the likely behavior scale is significantly higher than that on the personal values measure $\left(W=18572, p<.001, \eta^{2}=.45\right)$.

The average of the discrepancies between personal values and likely behavior in the different situations falls between .1 and .9. The greatest discrepancies can be found in the following situations: registering a younger sibling in a hiking group conducted by gay men $(M=.8, S D=1.2)$, signing up for a theatre course in which the majority of members are gay men $(M=.8, S D=1.2) /$ lesbian women $(M=.9, S D=1.2)$, and a gynaecological check-up with a lesbian physician $(M=.8, S D=1.4)$.

As can be seen in Table 2 the people who consider that they should feel more uncomfortable in contact with a gay man or lesbian woman (personal values) are those who hold religious beliefs, attend church, are older, and are married or separated. Those who say that they would feel uncomfortable in contact with a gay man or lesbian woman (likely behavior) tend to: be women, be married or separated, hold religious beliefs, attend church, and not report having gay or lesbian friends.

Finally, the results show that the discrepancy (the difference between likely behavior and personal values) is significantly greater in women, those who hold

religious beliefs, attend church, and do not report having gay or lesbian friends. In contrast, we found no significant differences according to age, marital status or academic qualifications, nor were there any differences with respect to the educational level or type of school at which the teachers worked.

\section{Subtle and Overt Prejudice Toward Homosexuals}

In terms of the Subtle and Overt Prejudice Toward Homosexuals Scale, and according to the classification of Quiles del Castillo et al., 3.3\% $(n=8)$ of teachers presented "fanatical attitudes" toward homosexuals (high score on overt and subtle homophobia), 9.2\% $(n=22)$ showed "subtle prejudice" (low score on overt homophobia and high on subtle), and $87.5 \%(n=210)$ adopted an "egalitarian stance" (low score on both overt and subtle prejudice). In this classification, it is significant that the teachers studied showed low prejudice scores, meaning that the division in these categories refers to the values within this group.

For the sample as a whole, the score for subtle (covert) homophobia $(M=2.8, S D=1.0)$ is significantly higher than that for overt (explicit) homophobia $(M=2.6$, $S D=.8), \eta^{2}=.11, W=36001, p=.004$. As can be seen in Table 3, those people who tend to show more prejudice hold religious beliefs, attend church, and do not report having gay or lesbian friends. With respect to age there were no significant differences in overt prejudice, although older people tended to show more subtle prejudice. In terms of marital status, common-law couples showed lower levels of prejudice than the other groups. In contrast, we found no significant differences with respect to academic qualifications or the level or type of school at which the teachers worked.

\section{Discussion}

The present study aimed to evaluate attitudes and prejudices about homosexuality in a group of teachers $(N=254)$. The teachers we have studied acknowledge that they would feel more uncomfortable than they should in relation to homosexual people. In general, greater discrepancies would occur in situations that involve more intimate physical contact with a homosexual person, the possibility of being identified as homosexual (when this is not the case), and proximity between a homosexual and a child. Davies (2004) suggests that attitudes towards gay men and lesbian women are a reflection of affective actions towards them and that certain items on a scale of attitudes might have more intense affective content than other items and, thus, might elicit responses involving a higher level of homophobia.

Sometimes, people with low prejudice consider that they have insufficient skills to behave in a non-prejudiced way, and this leads to a conflict between "how they should behave" (personal values) and "how they would actually behave" (likely behavior). The discrepancy, albeit low, is a possible indicator of prejudice: some studies have shown that individuals with both high and low prejudice may behave, under certain circumstances, in a clearly prejudicial way (Devine, 1989; Devine, Monteith, Zuwerink \& Elliot, 1991). The teachers who acknowledged a discrepancy between personal values and probable conduct would be more susceptible to acting according to the stereotypes on homosexuality that prevail in society, which are generally heterosexist (Herek, 2004).

Along these lines, Röndhal, Innala \& Carlsson (2007) found that only a minority of nurses had homophobic attitudes; nevertheless, the homosexuals treated claimed that these nurses used heteronormative language, which was perceived as insensitive, insulting and humiliating to gay men and/or lesbian women. They concluded that the nurses had to learn how to communicate more naturally and be aware of how they express their attitudes through their language and behavior. Something similar may hold true with teachers and their gay and/or lesbian students.

With respect to subtle and overt prejudice toward gay men and lesbian women, three groups of individuals were distinguished: "egalitarian stance" (87.5\%), "subtle prejudices" (9.2\%) and "fanatical attitudes" (3.3\%). Our results show considerably lower levels of homophobia 
Table 2

Scores on Personal Values, Likely Behavior and Discrepancy: differences according to variables

\begin{tabular}{|c|c|c|c|c|}
\hline & & Values & Behavior & Discrepancy \\
\hline & & $M(s d)$ & $M(s d)$ & $M(s d)$ \\
\hline \multicolumn{5}{|l|}{ Sex } \\
\hline Male & & $1.7(.8)$ & $2.4(1.2)$ & $.6(.9)$ \\
\hline \multirow[t]{2}{*}{ Female } & & $1.9(1.0)$ & $2.8(1.3)$ & $.9(1.0)$ \\
\hline & $p$ & .31 & $.05^{*}$ & $.05^{*}$ \\
\hline \multicolumn{5}{|l|}{ Age } \\
\hline-34 & & $1.8(.9)$ & $2.7(1.2)$ & $.9(.8)$ \\
\hline \multirow[t]{2}{*}{35 and over } & & $2.1(1.1)$ & $2.9(1.5)$ & $.8(1.1)$ \\
\hline & $p$ & $.04 *$ & .55 & .15 \\
\hline \multicolumn{5}{|l|}{ Marital status } \\
\hline Single & & $1.7(.9)$ & $2.5(1.2)$ & $.8(.9)$ \\
\hline Married & & $2.1(1.0)$ & $3.0(1.4)$ & $1.0(1.0)$ \\
\hline Separated & & $2.3(1.2)$ & $3.1(1.5)$ & $.7(1.2)$ \\
\hline \multirow[t]{2}{*}{ Long-term partner } & & $1.8(1.1)$ & $2.4(1.2)$ & $.6(.6)$ \\
\hline & $p$ & $.01 * * *$ & $.01 * * *$ & .11 \\
\hline \multicolumn{5}{|l|}{ Academic qualifications } \\
\hline Bachelor's degree & & $2.0(1.1)$ & $2.8(1.4)$ & $.7(.9)$ \\
\hline \multirow[t]{2}{*}{ Master's degree } & & $1.8(.8)$ & $2.7(1.3)$ & $1.0(1.0)$ \\
\hline & $p$ & .07 & .76 & .20 \\
\hline \multicolumn{5}{|l|}{ Educational level } \\
\hline Infant & & $2.0(1.0)$ & $2.8(1.3)$ & $.8(1.0)$ \\
\hline Primary & & $2.1(1.1)$ & $2.8(1.4)$ & $.8(.8)$ \\
\hline \multirow[t]{2}{*}{ Secondary } & & $1.8(.9)$ & $2.7(1.3)$ & $.9(1.0)$ \\
\hline & $p$ & .18 & .60 & .80 \\
\hline \multicolumn{5}{|l|}{ Type of school } \\
\hline Public & & $1.9(1.0)$ & $2.7(1.4)$ & $.8(1.0)$ \\
\hline Private & & $1.9(.9)$ & $2.9(1.6)$ & $.9(.9)$ \\
\hline \multirow[t]{2}{*}{ State-subsidized private } & & $2.0(1.0)$ & $2.8(1.2)$ & $.8(.9)$ \\
\hline & $p$ & .80 & .61 & .88 \\
\hline \multicolumn{5}{|c|}{ Do you have any religious beliefs? } \\
\hline Yes & & $2.1(1.1)$ & $3.0(1.4)$ & $1.0(1.0)$ \\
\hline \multirow[t]{2}{*}{ No } & & $1.7(.8)$ & $2.3(1.1)$ & $.7(1.0)$ \\
\hline & $p$ & $.01 * * *$ & $.01 * * *$ & $.01 * *$ \\
\hline \multicolumn{5}{|l|}{ Are you a churchgoer? } \\
\hline Yes & & $2.3(1.2)$ & $3.3(1.4)$ & $1.0(.9)$ \\
\hline \multirow[t]{2}{*}{ No } & & $1.8(.9)$ & $2.6(1.2)$ & $.8(1.0)$ \\
\hline & $p$ & $.01 * * *$ & $.01 * * *$ & $.04 *$ \\
\hline \multicolumn{5}{|c|}{ Do you have or have you had any gay male friends? } \\
\hline Yes & & $1.9(.9)$ & $2.6(1.3)$ & $.8(.9)$ \\
\hline \multirow[t]{2}{*}{ No } & & $2.1(1.3)$ & $3.2(1.5)$ & $1.1(1.0)$ \\
\hline & $p$ & .26 & $.01 * *$ & $.02 *$ \\
\hline \multicolumn{5}{|c|}{ Do you have or have you had any lesbian friends? } \\
\hline Yes & & $1.8(.9)$ & $2.5(1.3)$ & $.6(1.0)$ \\
\hline \multirow[t]{2}{*}{ No } & & $2.0(1.1)$ & $3.0(1.3)$ & $1.0(1.0)$ \\
\hline & $p$ & .33 & $.01 * * *$ & $.01 * * *$ \\
\hline
\end{tabular}

Note $^{*} p<.5 ; * * p<.01 ; * * * p<.001$ corresponding to Mann-Whitney or Wilcoxon tests. 
Table 3

Scores on Subtle and Overt Prejudice: differences according to the variables

\begin{tabular}{|c|c|c|c|}
\hline & & Overt prejudice & Subtle prejudice \\
\hline & & $M(s d)$ & $M(s d)$ \\
\hline \multicolumn{4}{|l|}{ Sex } \\
\hline Male & & $2.4(.7)$ & $3.1(1.0)$ \\
\hline \multirow[t]{2}{*}{ Female } & & $2.6(.9)$ & $2.8(1.1)$ \\
\hline & $p$ & .28 & .10 \\
\hline \multicolumn{4}{|l|}{ Age } \\
\hline-34 & & $2.5(.8)$ & $2.7(1.0)$ \\
\hline \multirow[t]{2}{*}{35 and over } & & $2.7(.9)$ & $3.0(1.1)$ \\
\hline & $p$ & .12 & $.01 * * *$ \\
\hline \multicolumn{4}{|l|}{ Marital status } \\
\hline Single & & $2.5(.8)$ & $2.7(1.0)$ \\
\hline Married & & $2.7(.8)$ & $3.1(1.0)$ \\
\hline Separated & & $2.5(1.0)$ & $3.2(1.2)$ \\
\hline \multirow[t]{2}{*}{ Long-term partner } & & $2.2(.8)$ & $2.3(.9)$ \\
\hline & $p$ & $.01 * * *$ & $.01 * * *$ \\
\hline \multicolumn{4}{|l|}{ Academic qualifications } \\
\hline Bachelor's degree & & $2.6(.9)$ & $2.9(1.0)$ \\
\hline \multirow[t]{2}{*}{ Master's degree } & & $2.5(.8)$ & $2.8(1.1)$ \\
\hline & $p$ & .65 & .52 \\
\hline \multicolumn{4}{|l|}{ Educational level } \\
\hline Infant & & $2.6(1.0)$ & $2.8(1.1)$ \\
\hline Primary & & $2.6(.8)$ & $3.0(1.0)$ \\
\hline \multirow[t]{2}{*}{ Secondary } & & $2.5(.8)$ & $2.7(1.0)$ \\
\hline & $p$ & .83 & .21 \\
\hline \multicolumn{4}{|l|}{ Type of school } \\
\hline Public & & $2.6(.9)$ & $2.9(1.2)$ \\
\hline Private & & $2.6(.8)$ & $2.8(1.1)$ \\
\hline \multirow[t]{2}{*}{ State-subsidized private } & & $2.5(.8)$ & $2.8(.9)$ \\
\hline & $p$ & .83 & .92 \\
\hline \multicolumn{4}{|c|}{ Do you have any religious beliefs? } \\
\hline Yes & & $2.8(.9)$ & $3.0(1.1)$ \\
\hline \multirow[t]{2}{*}{ No } & & $2.2(.7)$ & $2.5(.9)$ \\
\hline & $p$ & $.01 * * *$ & $.01 * * *$ \\
\hline \multicolumn{4}{|l|}{ Are you a churchgoer? } \\
\hline Yes & & $3.0(.9)$ & $3.3(1.1)$ \\
\hline \multirow[t]{2}{*}{ No } & & $2.4(.8)$ & $2.7(1.0)$ \\
\hline & $p$ & $.01 * * *$ & $.01 * * *$ \\
\hline \multicolumn{4}{|c|}{ Do you have or have you had any gay male friends? } \\
\hline Yes & & $2.4(.8)$ & $2.7(1.0)$ \\
\hline \multirow[t]{2}{*}{ No } & & $3.0(.8)$ & $3.3(1.1)$ \\
\hline & $p$ & $.01 * * *$ & $.01 * * *$ \\
\hline \multicolumn{4}{|c|}{ Do you have or have you had any lesbian friends? } \\
\hline Yes & & $2.3(.8)$ & $2.6(1.0)$ \\
\hline \multirow[t]{2}{*}{ No } & & $2.8(.8)$ & $3.1(1.0)$ \\
\hline & $p$ & $.01 * * *$ & $.01 * * *$ \\
\hline
\end{tabular}

Note. ${ }^{*} p<.5 ; * * p<.01 ; * * * p<.001$ corresponding to Mann-Whitney or Wilcoxon tests. 
than in the study of undergraduates carried out by Quiles del Castillo et al. This difference may be due to teachers being particularly sensitive to the issue of diversity in a wider sense (ethnic, cultural, sexual, etc.). Alternatively, it could be that teachers are more influenced than are undergraduates by what is regarded as socially desirable.

The score for subtle (covert) homophobia $(M=2.8$; $S D=1.0)$ was significantly higher than that for overt (explicit) homophobia $(M=2.6 ; S D=.8)$. This would indicate that the teachers in our sample, like society as a whole, tend to show prejudice in a more subtle and indirect way, as the obvious expression of such prejudice is not currently regarded as socially acceptable (Navas, 1997).

Our findings are similar to those reported by other studies (e.g., Berkman \& Zimberg, 1997; Johnson et al., 1997; Maney \& Cain, 1997; Satcher \& Leggett, 2007; Toro-Alfonso \& Varas Díaz, 2004) with respect to the relationship between homophobia and religious beliefs. Indeed, people who claim to have religious beliefs and who are churchgoers score highest on both overt and subtle prejudice, and evidence the greatest discrepancy between personal values and likely behavior. The view of homosexuality as something undesirable, immoral and sinful may well be more frequent in people with religious beliefs (Toro-Alfonso \& Varas-Díaz, 2007). Our results also support previous research that has shown greater homophobia to be associated with a lack of contact with gay men and lesbian women (e.g., Berkman \& Zinberg, 1997; Cullen et al., 2002; Sakalli, 2002; Shidlo, 1994). Proximity to, and interaction with, gay men and lesbian women might enable individuals to compare the stereotyped views of homosexuality, thus lowering this prejudice. Another possible interpretation is that people with less prejudice enter into relationships with gay men or lesbian women more frequently. Most likely these three variables -"religious beliefs", "churchgoers", and "lack of contact with gay men and lesbian women"-, are interrelated, but in an observational study it is always debatable whether one can talk about causality.

Given the nature of this study, the results may not be generalized to the general population and may not reveal a characteristic exclusive to teachers, despite the fact those teachers more than other groups may tend to present themselves as non-prejudiced individuals. In this regard, it should be borne in mind that there is now a strong tendency within Spanish society for people to present themselves as unprejudiced and, in general, there is a predominance of "politically correct" ideas. For example, in a survey conducted by the government of Spain's Centro de Investigaciones Sociológicas (CIS, 2004), 79\% of the interviewees regarded "homosexuality as a personal option that is as valid as heterosexuality", while $11.4 \%$ of the respondents disagreed with this statement. A social desirability scale should be administered in future studies.
Women are over-represented in our sample of secondary school teachers, accounting for $75 \%$ compared to $22.9 \%$ of women as a whole among all the secondary school teachers in Barcelona (Departament d'Educació de la Generalitat de Catalunya, 2005). In further studies, the sample of male secondary school teachers should be expanded.

In conclusion, the findings of our study underscore the importance of studying levels of prejudice toward gay men and lesbian women in a group of people with educational responsibility for preventing homophobic attitudes and inequality. Education in values is a core function of the school (and obviously the family), and teachers are reference models. This study underscores the risk of this educational function failing if children and adolescents perceive in their teachers a distance between what should be and what is, between what one should do and what one really does (Coll, 1998). Interventions aimed at reducing homophobia among teachers, their pupils and, probably, society as a whole should seek to promote greater contact between people of different sexual orientations. Expanding teachers' specific information on diversity and helping them to examine their own beliefs and values on homosexuality would enable us to lower the transmission of prejudicial attitudes. We hope that this study will encourage researchers to focus on understanding homosexuality and other people's attitudes toward it. Increased systematic research has considerable potential to contribute to efforts to reduce prejudices against gay men and lesbian women.

\section{References}

Ben-Ari, A. T. (1998). An experiential attitude change: Social work students and homosexuality. Journal of Homosexuality, 36(2), 59-71.

Benkov, L. (1994). Reinventing the family: Lesbian and gay parents. New York, NY: Crown.

Berkman, C. S., \& Zinberg, G. (1997). Homophobia and heterosexism in social workers. Social Work, 42(4), 319-332.

Bowers, R., Plummer, D., \& Minichiello, V. (2005). Homophobia in counselling practice. International Journal for the Advancement of Counselling, 27(3), 471-489.

Buston, K., \& Hart, G. (2001). Heterosexism and homophobia in Scottish school sex education: Exploring the nature of the problem. Journal of Adolescence, 24(1), 95-109.

Centro de Investigaciones Sociológicas (2004). Barómetro de Junio de 2004. Estudio $\mathrm{n}^{\circ}$ 2568. Madrid: Centro de Investigaciones Sociológicas, Ministerio de la Presidencia, Gobierno de España.

Coll, C. (1998). Valores predicados, valores practicados, valores enseñados. Infancia y Aprendizaje, 21(2), 63-64.

Cullen, J. M., Wright, L. W., \& Alessandri, M. (2002). The personality variable openness to experience as it relates to homophobia. Journal of Homosexuality, 42(4), 119-134. 
Davies, M. (2004). Correlates of negative attitudes toward gay men: sexism, male role norms, and male sexuality. Extracted on August 1, 2004, from http://www.encyclopedia.com/ printable.aspx?id=1G1:123120061.

Departament d'Educació de la Generalitat de Catalunya (2005). Extracted on March 10, 2007, from http://www20.gencat.cat/ portal/site/Educacio.

Devine, P. G. (1989). Stereotypes and prejudice: Their automatic and controlled components. Journal of Personality and Social Psychology, 56, 5-18.

Devine, P. G., Monteith, M. J., Zuwerink, J. R., \& Elliot, A. J. (1991). Prejudice with and without compunction. Journal of Personality and Social Psychology, 60, 817-830.

Donnelly, J., Donnelly, M., Kittleson, M. J., Fogarty, K. J., Procaccino, A. T., \& Duncan, D. F. (1997). An exploration of attitudes on sexuality at a northeastern urban university. Psychological Reports, 81(2), 677-688.

España A., Guerrero, A., Farré, J. M., Canella-Soler, J., \& Abós, R. (2001). La homofobia en el medio universitario. Un estudio empírico. Cuadernos de Medicina Psicosomática y Psiquiatría de Enlace, 57, 41-55.

Espelt, E., Javaloy, F., \& Cornejo. J. M. (2006). Las escalas de prejuicio manifiesto y sutil: ¿una o dos dimensiones? Anales de Psicología, 22(1), 81-88.

Farr, M. T. (2000). “Everything I didn't want to know I learned in lit class": Sex, sexual orientation, and student identity. International Journal of Sexuality and Gender Studies, 5(2), 205-213.

Herek, G. M. (2004). Beyond "homophobia": Thinking about sexual stigma and prejudice in the twenty-first century. Sexuality Research and Social Policy, 1(2), 6-24.

Johnson, M. E., Brems, C., \& Alford-Keating, P. (1997). Personality correlates of homophobia. Journal of Homosexuality, 34(1), 57-69.

Jones, M. K., Pynor, R. A., Sullivan, G., \& Weerakoon, P. (2002). A study of attitudes toward sexuality issues among health care students in Australia. Journal of Lesbian Studies, 6(34), 73-86.

Keuzenkamp, S., \& Bos, D. (2007). Out in the Nertherlands. Acceptance of homosexuality in the Netherlands. The Hague: The Netherlands Institute for Social Research.

Kochenderfer-Ladd, B., \& Pelletier, M. E. (2007). Teachers' views and beliefs about bullying: Influences on classroom management strategies and students' coping with peer victimization. Journal of School Psychology, 46, 431-453.

Lieblich, A., \& Friedman, G. (1985). Attitudes toward male and female homosexuality and sex-role stereotypes in Israeli and American students. Sex Roles, 12(5-6), 561-570.

Lingiardi, V., Falanga, S., \& D'Augelli, R. (2005). The evaluation of homophobia in an Italian sample. Archives of Sexual Behavior, 34(1), 81-93.

Maney, D. W., \& Cain, R. E. (1997). Preservice elementary teachers' attitudes toward gay and lesbian parenting. The Journal of School Health, 67(6), 236-241.
Marinho, C. de A., Marques, E. F. M., Almeida, D. R., Menezes, A. R. B., \& Guerra, V. M. (2004). Adaptaçao da escala de homofobia implícita e explícita ao contexto brasileiro. Cadernos de Psicologia e Educaçao Paideia, 14(29), 371-379.

Martínez, B. (2005). Las medidas de respuesta a la diversidad: posibilidades y límites para la inclusión escolar y social. Profesorado, revista de currículum y formación del profesorado, 1(1), 1-30.

Matchinsky, D. J., \& Iverson, T. G. (1996). Homophobia in heterosexual female undergraduates. Journal of Homosexuality, 31(4), 123-128.

Montero, M. L. (2000). La formación del profesorado ante los retos de la multiculturalidad. Profesorado, revista de currículum y formación del profesorado, 4(1), 1-20.

Morrison, M. A., \& Morrison, T. G. (2002). Development and validation of a scale measuring modern prejudice toward gay men and lesbian women. Journal of Homosexuality, 43(2), 15-37.

Morrow, R. G., \& Gill, D. L. (2003). Perceptions of homophobia and heterosexism in physical education. Research Quarterly for Exercise and Sport, 74(2), 205-214.

Navas, M. S. (1997). El prejuicio presenta un nuevo rostro: puntos de vista teóricos y líneas de investigación recientes sobre un problema familiar. Revista de Psicología Social, 12(2), 201-237.

Pettigrew, T. E., \& Meertens, R. W. (1995). Subtle and blatant prejudice in Western Europe. European Journal of Social Psychology, 25, 57-75.

Proulx, R. (1997). Homophobia in northeastern Brazilian university students. Journal of Homosexuality, 34(1), 47-56.

Quiles del Castillo, N., Betancor, V., Rodríguez, R., Rodríguez, A., \& Coello, E. (2003). La medida de la homofobia manifiesta y sutil. Psicothema, 15(2), 197-204.

Röndahl, G., Innala, S., \& Carlsson, M. (2004). Nurses' attitudes towards lesbians and gay men. Journal of Advanced Nursing, 47(4), 386-392.

Röndahl, G., Innala, S., \& Carlsson, M. (2007). To hide or not to hide, that is the question! Lesbians and gay men describe experiences from nursing work environment. Journal of Homosexuality, 52(3-4), 211-33.

Sakalli, N (2002). The relationship between sexism and attitudes toward homosexuality in a sample of Turkish college students. Journal of Homosexuality, 42(3), 53-64.

Sánchez, A. (2002). La escuela coeducativa: un modelo de equidad en las aulas. Padres y Maestros, 268, 18-21.

Satcher, J., \& Leggett, M. (2007). Homonegativity among professional school counselors: An exploratory study. Professional School Counseling, 11(1), 10-16.

Shidlo, A. (1994). Assessing heterosexuals' attitudes toward lesbian and gay men. In B. Greene, \& G. M. Herek, (Eds.), Psychological perspectives on lesbian and gay issues, vol. 1 Lesbian and gay psychology: Theory, research, and clinical applications (pp. 176-205). Thousand Oaks, CA: Sage.

Smith, D. M., \& Mathews, W. C. (2007). Physicians' attitudes toward homosexuality and HIV: survey of a California 
Medical Society-revisited (PATHH-II). Journal of Homosexuality, 52(3-4), 1-9.

Span, S. A., \& Vidal, L. A. (2003). Cross-cultural differences in female university students' attitudes toward homosexuals: A preliminary study. Psychological Reports, 92(2), 565-572.

Steffens, M. C. (2005). Implicit and explicit attitudes towards lesbians and gay men. Journal of Homosexuality, 49(2), 39-66.

Toro-Alfonso, J., \& Varas-Díaz, N. (2004). Los otros: prejuicio y distancia social hacia hombres gay y lesbianas en una muestra de estudiantes de nivel universitario. International Journal of Clinical and Health Psychology, 4(3), 537-551.
Van de Ven, P. (1995). Effects on high school students of a teaching module for reducing homophobia. Basic and Applied Social Psychology, 17(1-2), 153-172.

Waterman, A. D., Reid, J. D., Garfield, L. D., \& Hoy, S. J. (2001). From curiosity to care: Heterosexual students' interest in sexual diversity courses. Teaching of Psychology, 28(1), 21-26.

Received July 30, 2008

Revision received April 17, 2009

Accepted May 4, 2009 


\section{APPENDIX}

\section{DISCREPANCY SCALE BETWEEN PERSONAL VALUES AND LIKELY BEHAVIOR ${ }^{1}$}

\section{Part I}

In this questionnaire, we will explore your perception of sexual diversity, specifically on your perception of gay men. In the following questionnaire, we will ask you about lesbian women.

The questions you will find below describe everyday situations. Your job is to indicate the following using two seven-point scales:

1) how you think YOU SHOULD FEEL in this situation according to your personal values, and

2) how you think YOU REALLY WOULD FEEL based on your past experience.

Let us look at the example below:

\section{Situation 0}

Imagine that you have to make a phone call and there is someone in the phone booth who is taking a long time finishing their conversation.

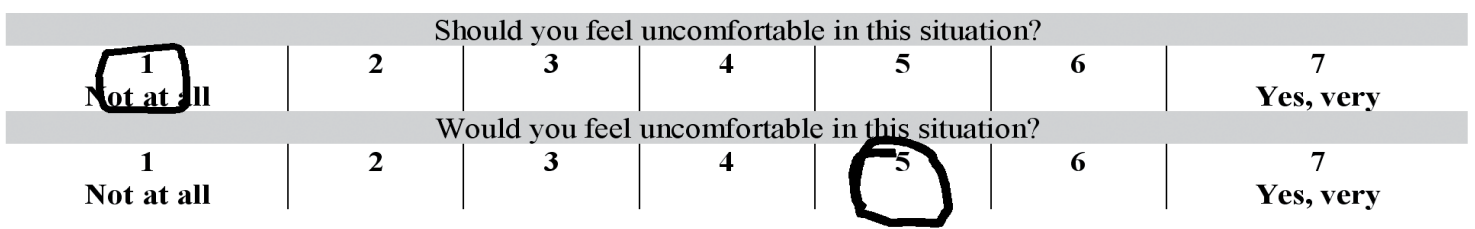

The person who has responded to this scale thinks that they should not feel uncomfortable with this situation, yet they also acknowledge that they cannot help feeling uncomfortable in reality.

As you can see, the first question aims to find out what you think you should feel according to your personal values, while the second probes how you would really feel, that is, what feeling you would most likely have in this situation.

\footnotetext{
1 This scale has been developed based on the Escala de discrepancia entre norma personal y conducta probable (Quiles del Castillo, N., Betancor, V., Rodríguez, R., Rodríguez, A. and Coello, E., 2003).
} 


\section{Situation 1}

Imagine that a gay man gets on the bus and sits right next to you.

Should you feel uncomfortable because a gay man sits next to you?

\begin{tabular}{|c|c|c|c|c|c|c|}
\hline $\begin{array}{c}1 \\
\text { Not at all }\end{array}$ & 2 & 3 & 4 & 5 & 6 & $\begin{array}{c}7 \\
\text { Yes, very }\end{array}$ \\
\hline \multicolumn{7}{|c|}{ Would you feel uncomfortable if a gay man sat next to you? } \\
\hline $\begin{array}{c}1 \\
\text { Not at all }\end{array}$ & 2 & 3 & 4 & 5 & 6 & $\begin{array}{c}7 \\
\text { Yes, very }\end{array}$ \\
\hline
\end{tabular}

\section{Situation 2}

Imagine that you show up at an interview for a job you are very interested in, and the person interviewing you is a gay man.
Should you feel uncomfortable because a gay man is interviewing you?

\begin{tabular}{|c|c|c|c|c|c|c|}
\hline \multicolumn{7}{|c|}{ should you teel uncomrortable because a gay man is interviewing you? } \\
\hline $\begin{array}{c}1 \\
\text { Not at all }\end{array}$ & 2 & 3 & 4 & 5 & 6 & $\begin{array}{c}7 \\
\text { Yes, very }\end{array}$ \\
\hline \multicolumn{7}{|c|}{ Would you feel uncomfortable if a gay man interviewed you? } \\
\hline $\begin{array}{c}1 \\
\text { Not at all }\end{array}$ & 2 & 3 & 4 & 5 & 6 & $\begin{array}{c}7 \\
\text { Yes, very }\end{array}$ \\
\hline
\end{tabular}

\section{Situation 3}

Imagine that lately you have been having a lot of problems and decide to seek the help of a therapist. When you reach the office, you see that the therapist is a gay man.
Should you feel uncomfortable because your therapist is a gay man?

\begin{tabular}{|c|c|c|c|c|c|c|}
\hline $\begin{array}{c}1 \\
\text { Not at all }\end{array}$ & 2 & 3 & 4 & 5 & 6 & $\begin{array}{c}7 \\
\text { Yes, very }\end{array}$ \\
\hline \multicolumn{7}{|c|}{ ould you feel uncomfortable if your therapist were a gay man? } \\
\hline $\begin{array}{c}1 \\
\text { Not at all }\end{array}$ & 2 & 3 & 4 & 5 & 6 & $\begin{array}{c}7 \\
\text { Yes, very }\end{array}$ \\
\hline
\end{tabular}

\section{Situation 4}

Imagine that you encourage your younger brother to join a hiking group so he can learn how to get along with other children and shed some of his shyness. When you take your brother to the hiking centre, you realise that several of the leaders are gay men.

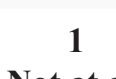

Not at all

Not at all

Should you feel uncomfortable when you realise that the leaders are gay men?

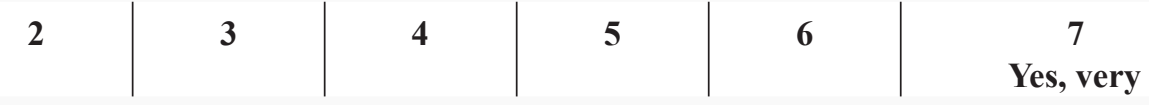

Would you feel uncomfortable if you found out that the leaders were gay men?

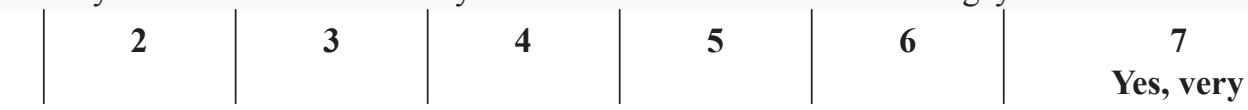




\section{Situation 5}

Imagine that you have to do a project for several classes and a man in your class, whom everyone knows is gay, says that he would like to do the project with you.

\begin{tabular}{|c|c|c|c|c|c|c|}
\hline \multicolumn{7}{|c|}{ Should you feel uncomfortable working with a gay man? } \\
\hline $\begin{array}{c}1 \\
\text { Not at all }\end{array}$ & 2 & 3 & 4 & 5 & 6 & $\begin{array}{c}7 \\
\text { Yes, very }\end{array}$ \\
\hline \multicolumn{7}{|c|}{ Would you feel uncomfortable if you had to work with a gay man? } \\
\hline $\begin{array}{c}1 \\
\text { Not at all }\end{array}$ & 2 & 3 & 4 & 5 & 6 & $\begin{array}{c}7 \\
\text { Yes, very }\end{array}$ \\
\hline
\end{tabular}

\section{Situation 6}

Imagine that your partner left you for a person of the same sex.

Should you feel particularly uncomfortable because your partner left you for someone of the same sex?

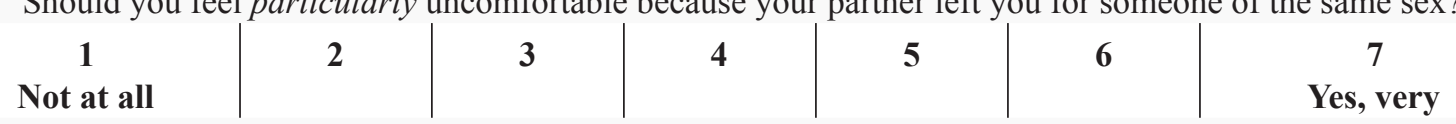

Not at all

Would you feel particularly uncomfortable if partner left you for someone of the same sex?

\begin{tabular}{c|l|l|l|l|l|l}
1 & 2 & 3 & 4 & 5 & 6 & 7 \\
Not at all & & & & & & Yes, very
\end{tabular}

\section{Situation 7}

Imagine that you sign up to take a theatre course, and when you get there you realise that most of the people in the class are gay men.

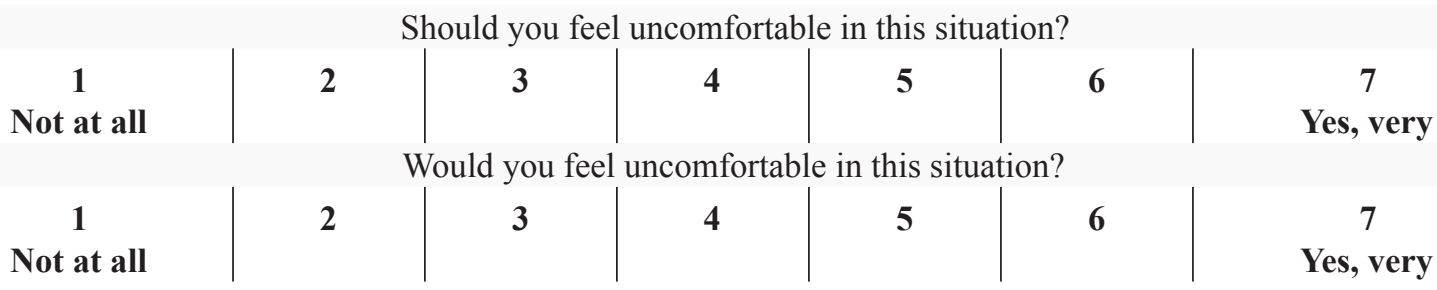

\section{Situation 8}

Imagine that you go for a medical check-up that involves a genital exploration, and once you are in the office you realise that the physician is a gay man.

Should you feel uncomfortable because the physician is gay?

\begin{tabular}{l|l|l|l|l|l|c}
$\begin{array}{c}1 \\
\text { Not at all }\end{array}$ & $\mathbf{2}$ & $\mathbf{3}$ & $\mathbf{4}$ & $\mathbf{5}$ & $\mathbf{6}$ & $\mathbf{7}$ \\
$\begin{array}{c}\mathbf{1} \\
\text { Not at all }\end{array}$ & $\mathbf{2}$ & $\mathbf{3}$ & $\mathbf{4}$ & $\mathbf{5}$ & $\mathbf{6}$ & Yes, very \\
\end{tabular}




\section{Part II}

In the previous questionnaire, we asked for your perception on gay men. In this one, we will ask your opinion on lesbian women.

Situation 1

Imagine that a lesbian woman gets on the bus and sits right next to you
Should you feel uncomfortable because a lesbian woman sits next to you?

\begin{tabular}{l|c|c|c|c|c|c}
$\begin{array}{c}1 \\
\text { Not at all }\end{array}$ & $\mathbf{2}$ & $\mathbf{3}$ & $\mathbf{4}$ & $\mathbf{6}$ & $\mathbf{7}$ \\
Yes, very
\end{tabular}

Situation 2

Imagine that you show up at an interview for a job you are very interested in, and the person interviewing you is a lesbian.

\begin{tabular}{|c|c|c|c|c|c|c|}
\hline \multicolumn{7}{|c|}{ Should you feel uncomfortable because a lesbian is interviewing you? } \\
\hline $\begin{array}{c}1 \\
\text { Not at all }\end{array}$ & 2 & 3 & 4 & 5 & 6 & $\begin{array}{c}7 \\
\text { Yes, very }\end{array}$ \\
\hline \multicolumn{7}{|c|}{ Would you feel uncomfortable if a lesbian interviewed you? } \\
\hline $\begin{array}{c}1 \\
\text { Not at all }\end{array}$ & 2 & 3 & 4 & 5 & 6 & $\begin{array}{c}7 \\
\text { Yes, very }\end{array}$ \\
\hline
\end{tabular}

Situation 3

Imagine that lately you have been having a lot of problems and decide to seek the help of a therapist. When you reach the office, you see that the therapist is a lesbian.

Should you feel uncomfortable because your therapist is a lesbian?
1
2
3
4
5
6
7
Not at all
Would you feel uncomfortable if your therapist were a lesbian?
1
Not at all
2

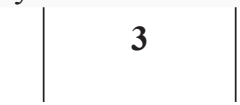
4
5
6
Yes, very
7
Yes, very

Situation 4

Imagine that you encourage your younger brother to join a hiking group so that he can learn how to get along with other children and shed some of his shyness. When you take your brother to the hiking centre, you realise that several of the leaders are lesbians.

Should you feel uncomfortable when you realise that the leaders are lesbians?

1

Not at all
2

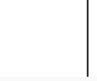

3
4
5

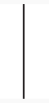

6
7

Would you feel uncomfortable if you found out that the leaders were lesbians? 
\begin{tabular}{c|l|l|l|l|l|l}
1 & 2 & 3 & 4 & 5 & 6 & 7 \\
Not at all & & & & & 5 & Yes, very
\end{tabular}

Situation 5

Imagine that you have to do a project for several classes and a woman in your class, whom everyone knows is a lesbian, says that she would like to do the project with you.

\begin{tabular}{|c|c|c|c|c|c|c|}
\hline \multicolumn{7}{|c|}{ Should you feel uncomfortable working with a lesbian? } \\
\hline $\begin{array}{c}1 \\
\text { Not at all }\end{array}$ & 2 & 3 & 4 & 5 & 6 & $\begin{array}{c}7 \\
\text { Yes, very }\end{array}$ \\
\hline \multicolumn{7}{|c|}{ Would you feel uncomfortable if you had to work with a lesbian? } \\
\hline $\begin{array}{c}1 \\
\text { Not at all }\end{array}$ & 2 & 3 & 4 & 5 & 6 & $\begin{array}{c}7 \\
\text { Yes, very }\end{array}$ \\
\hline
\end{tabular}

Situation 6

Imagine that you sign up to take a theatre course, and when you get there you realise that most of the women in the class are lesbians.

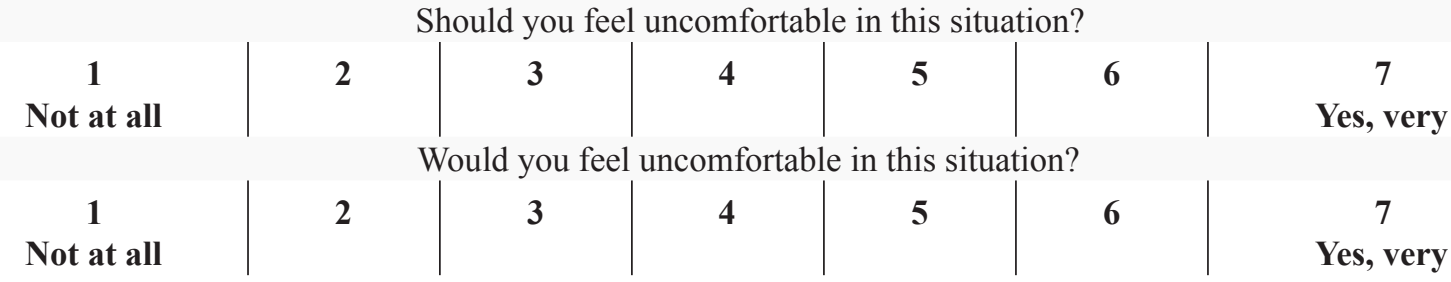

\section{Situation 7}

Imagine that you go for a medical check-up that involves a genital exploration, and once you are in the office you realise that the physician is a lesbian.
Should you feel uncomfortable because the physician is a lesbian?

\begin{tabular}{l|c|c|c|c|c|c}
$\begin{array}{c}1 \\
\text { Not at all }\end{array}$ & $\mathbf{2}$ & $\mathbf{3}$ & $\mathbf{4}$ & $\mathbf{5}$ & $\mathbf{6}$ & $\begin{array}{c}7 \\
\text { Yes, very }\end{array}$ \\
$\begin{array}{c}\mathbf{1} \\
\text { Not at all }\end{array}$ & $\mathbf{2}$ & $\mathbf{3}$ & $\mathbf{4}$ & $\mathbf{5}$ & $\mathbf{6}$ & $\mathbf{7}$ \\
Would you feel uncomfortable if the physician were a lesbian? &
\end{tabular}




\section{Scale of subtle and overt prejudice towards homosexuals ${ }^{2}$}

1. There are many homosexual groups who are pressing to get more rights, but politicians forget about the problems that heterosexuals have, like when they decide to have a child.

Disagree

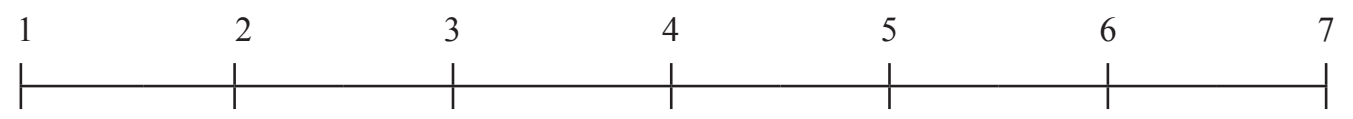

2. Deep down, homosexuals are the same as heterosexuals.

\section{Disagree}

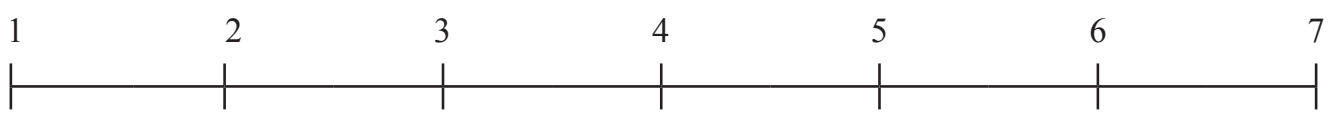

3. Many homosexuals have fairly prominent social and economic status, but they have achieved it precisely because of their sexual orientation and the support they get from other homosexuals.

Disagree

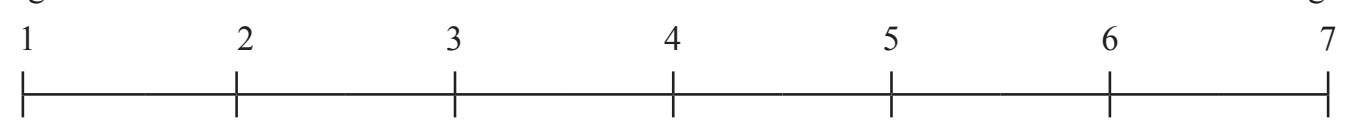

4. Homosexuals and heterosexuals will never feel at home with one another even if they are friends.

Disagree

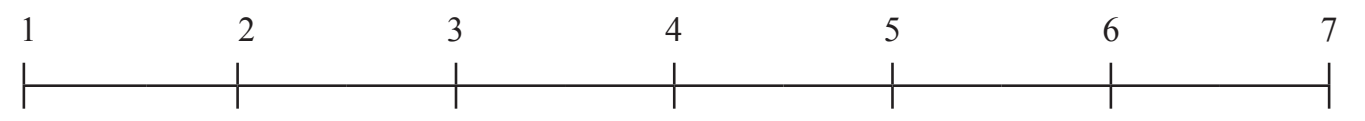

5. Because of their sexual orientation, homosexuals will never achieve the same level of personal development as heterosexuals.

Disagree

Agree

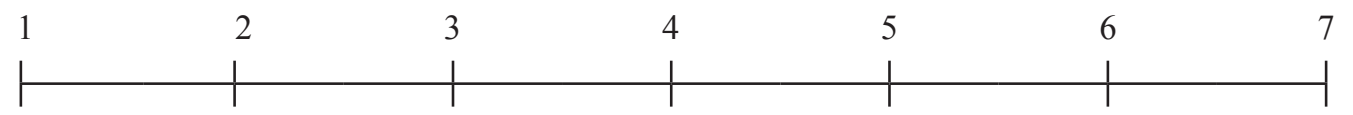

2 This scale was developed based on the Escala de prejuicio sutil y manifiesto hacia los homosexuales (Quiles del Castillo, N., Betancor, V., Rodríguez, R., Rodríguez, A. and Coello, E., 2003). 
6. If I have/had a daughter, I would be upset if she were a lesbian and in an intimate relationship with another woman.

Disagree

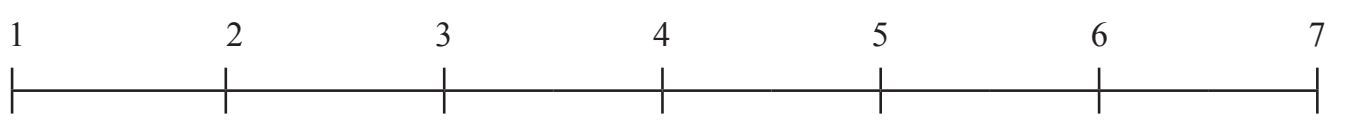

7. If I have/had a son, I would be upset if he were gay and in an intimate relationship with another man.

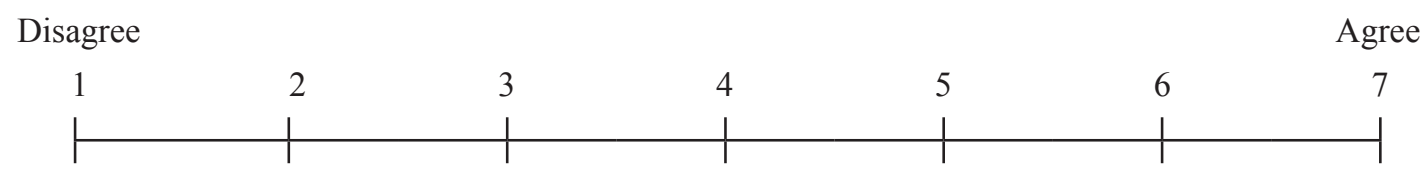

8. At my job, I would be upset if my boss were gay, even if he had all the right degrees and experience.

Disagree

Agree

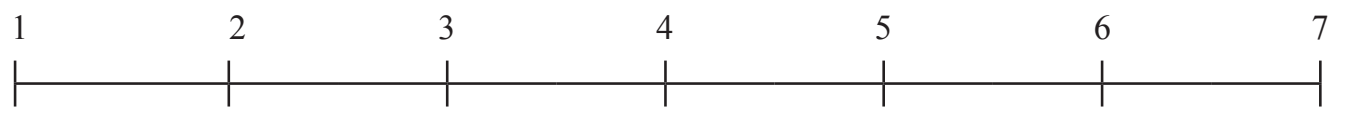

9. At my job, I would be upset if my boss were a lesbian, even if she had all the right degrees and experience.

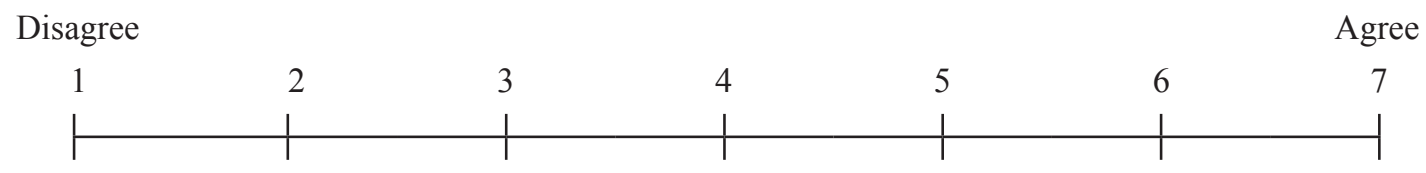

10. If it were the case, I would not mind if a gay man or lesbian were in an intimate relationship with one my family members.

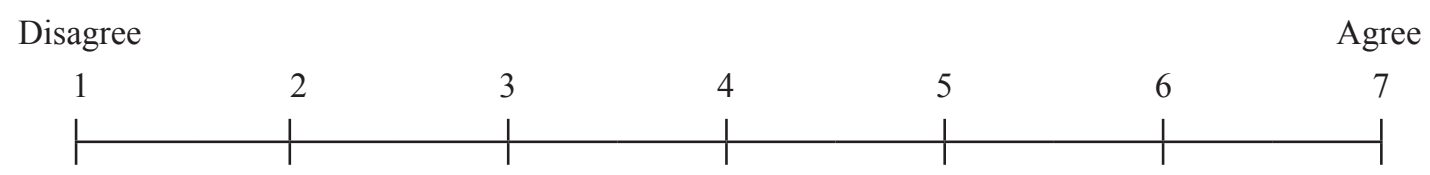

11. Just like immigrants adopt the customs of their new country, I think that homosexuals could do the same and be more moderate.

Disagree

Agree

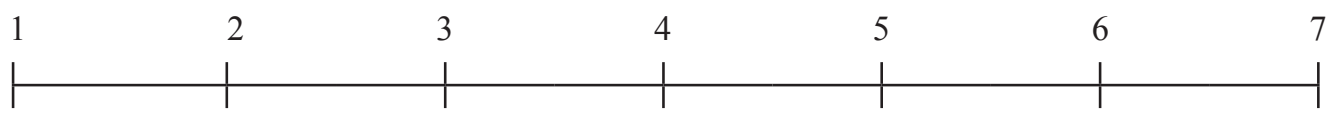


12. The ideas that homosexuals might inculcate in children are quiet different to those that a heterosexual might convey.

Disagree

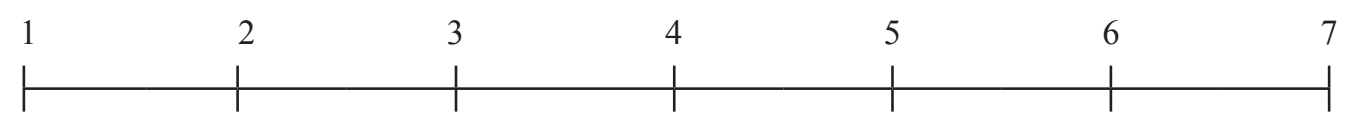

13. If homosexuals truly tried to integrate, there would be no need for so many demonstrations or for them to be in the closet.

Disagree

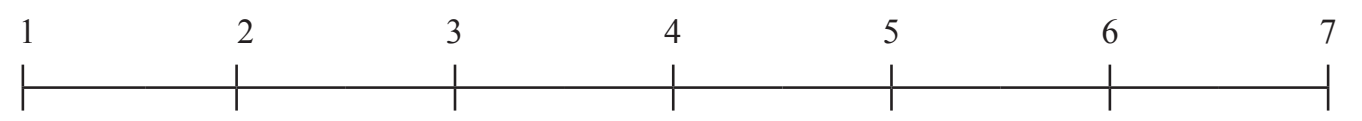

14. I think that homosexuals' religious and ethical values are different to those of heterosexuals.

Disagree

Agree

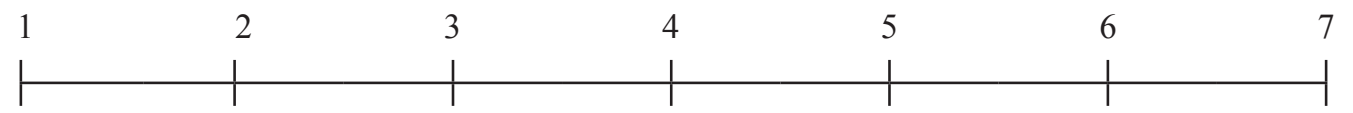

15. I think that there are many differences in homosexuals' and heterosexuals' beliefs and ideas.

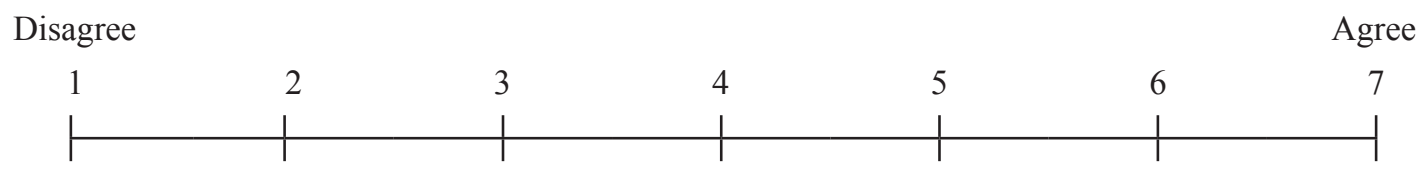

